DOI https://doi.org/10.18551/rjoas.2018-02.25

\title{
CROP GROWTH PARAMETERS OF GRAIN SORGHUM VARIETIES (SORGHUM BICOLOR (L.) MOENCH) AT DIFFERENT CROP SPACING
}

\author{
Pollo R.* \\ Department of Agrotechnology, Faculty of Agriculture, University of Nusa Cendana, \\ Nusa Tenggara Timur Province, Indonesia \\ Sitompul S.M., Guritno B., Tyasmoro Y.S. \\ Department of Agroechotechnology, Faculty of Agriculture, University of Brawijaya, \\ East Java Province, Indonesia \\ *E-mail: proddialek@gmail.com
}

\begin{abstract}
This research aimed at determining morphology, yield and photosynthesis partition of sorghum varieties at different crop spacing had been done at Agro Techno Park of University of Brawijaya (East Java, Indonesia). Observations on crop growth parameters were performed for 4 times $(25,50,75$, and 100 days after planting) which consisted of total leaf area, specific leaf area, leaf area index, crop growth rate and net assimilation rate. The crop spacing of $70 \mathrm{~cm} \times 25 \mathrm{~cm}$ proved to provide better value for most parameters, except for crop growth rate and specific leaf area which used $70 \mathrm{~cm} \times 15 \mathrm{~cm}$ crop spacing.
\end{abstract}

\section{KEY WORDS}

Sorghum, crop spacing, crop growth, morphology.

Sorghum is a potential commodity and has high economic value because it can be used as food, feed, and export commodities. The people of Rote Ndao Regency (RoNda), Timor Island and its surrounding islands (East Nusa Tenggara Province, NTT) name it as a "rote corn (jagung rote)", which is thought to be due to its visual resemblance to corn crops. In this region, sorghum has become an alternative functional food for generations, in addition to rice and corn. However, to the present, the productivity is still low, about $0.37-1.80$ tons ha $^{-1}$, which makes sorghum has not taken farmers' interest as a commercial commodity. In fact, if it is cultivated with a touch of adequate technology, the results can reach 11 tons ha $^{-1}$ of seeds, with an average of 7-9 tons ha ${ }^{-1}$ of seeds (House, 1985, Balitbangtan Kementan, 2013) or total dry material above ground level of 27.2 tons ha $^{-1}$ (Garofalo et al., 2011).

The low production is presumed because sorghum is cultivated simply, it has irregular spacing, and only acts as a limiting crop/fencing crop (to protect the main rice commodities), as practiced by 'rote corn' farmers in RoNda District. Therefore, it is necessary to know the factors that affect the crops through the crop growth analysis approach that aims to determine what environmental factors affect growth and yield (Biscoe and Wellington, 1984). Numerous studies have shown that crop growth and development are influenced by genetic factors (varieties) and environmental factors such as temperature, flux and PAR duration (photosynthetically active radiation), availability of nutrients and water, and loss of photosynthetic tissues (Russelle et al., 1984; Shipley, 2006; Ahad, 1986 in Özalkan et al., 2010).

Crop growth analysis is an important approach for assessing the growth and productivity of crops (Wilson, 1981) or the basic technique used to measure growth components, as a first step in primary production analysis, and is the most practical method for assessing net photosynthetic production (Nogueira et al., 1994) or a quantitative method for describing and interpreting the overall crop system's well-being that grows under natural, semi-natural and controlled conditions (Hunt, 2003). This method can be approached on the individual crop or planting area by using the average of leaf area ratio (LAR), net assimilation rate (NAR), and other similar functions to describe crop growth (Russelle et al., 1984) or by 
using primary data such as weight, areas, volumes, and specific contents of crops or crop components to inactivate processes involving whole crops or harvested crops (Hunt, 2003) because growth processes (CGR and NAR) directly affect the economic results of crops (Srivastava and Singh, 1980).

The approach in crop growth analysis includes a number of parameters such as Crop Growth Rate (CGR), Unit Leaf Rate or ULR (also called as Net Assimilation Rate, NAR), Specific Leaf Area (SLA), and Leaf Weight Fraction (LWF) (Watson and Hayashice, 1965; Buttery, 1969; Poorter and Remkes, 1990; Karimi and Siddique, 1991; Hunt et al., 2002; Shipley, 2006; Poorter et al., 2009; Gul et al., 2013; Rahnama , 2006 in Ahmadi, Rad, and Delkhosh, 2014; Li et al., 2016):

$$
\begin{aligned}
& C G R=N A R \times L A I=(R G R \times L A I) /(S L A \times L W F)=(R G R \times L A I) /(L A R) \\
& R G R=U L R(\text { atau } N A R) \times L A R \\
& L A R=\frac{\frac{L A_{1}}{W_{1}}+\frac{L A_{2}}{W_{2}}}{2} \quad L W R=\frac{\frac{L W_{1}}{W_{1}}+\frac{L W_{2}}{W_{2}}}{L} \quad L W F=\frac{\frac{L A_{1}}{L W_{1}}+\frac{L A_{2}}{L W_{2}}}{2} \\
& \left(\frac{1}{W}\right)\left(\frac{d W}{d t}\right)=\left(\frac{1}{L A}\right)\left(\frac{d W}{d t}\right) \times\left(\frac{L A}{L W}\right) \times\left(\frac{L W}{W}\right) \\
& (R G R) \quad(U L R) \quad(S L A) \quad(L W F)
\end{aligned}
$$

Where $t=$ time, $W$ is the total dry weight per crop, LA is the total leaf area per crop, LW is the total dry weight of leaf per crop, LAl is the Leaf Area Index, and LWF is the Leaf Heavy Fraction, synonymous with LWR (Leaf Weight Ratio). CGR is the result of multiplication between NAR and LAI, whereas the result of SLA (ratio of leaf area per unit of leaf weight) and LWF (ratio of leaf weight per total of crop weight) is called as LAR (Leaf Area Ratio).

\section{MATERIALS AND METHODS OF RESEARCH}

The research was conducted from September to December 2015 at Agro Techno Park location of Faculty of Agriculture, University of Brawijaya (FPUB) in Jatikerto Village, Kromengan Subdistrict, Malang Regency, East Java Province, Indonesia and at a laboratory (Agro Techno Park, Crop Physiology, and Soil Chemistry of FPUB) located at 112.27$112.32^{\circ}$ of East Longitude and $8.08-8.05^{\circ}$ of South Latitude, $321 \mathrm{~m}$ above sea level. The climatic conditions of the site at the time of the study were carried out were as follows: the average temperature was $24.6-27.8^{\circ} \mathrm{C}$, the air humidity was $71-86 \%$, the rainfall rate was $1948.6 \mathrm{~mm}$ per year (with 7 wet months and 126 rainy days) and solar radiation of $41-81 \%$ (Geophysics Station of Karangkates Malang, 2015).

The materials used in this study were sorghum seed, urea fertilizer with the dose of $200 \mathrm{~kg} \mathrm{ha}^{-1}, \mathrm{SP}-36$ with the dose of $100 \mathrm{~kg} \mathrm{ha}^{-1}$ (recommended dosage/ recommendation for sorghum) and $\mathrm{KCl}$ of $100 \mathrm{~kg} \mathrm{ha}^{-1}$, Furadan 3-G , pesticides, and fungicides. The superior varieties used were Numbu, Kawali, Super 1, and Super 2 obtained from Balitsereal, Maros, South Sulawesi Province, while the local variety of Rote was obtained from the sorghum farmer from RoNda District.

The tools used were luxmeter, PS 1200 type Nict Voor scale, 21037 FNR type Memmert oven, leaf area meter (LAM), freezer, tissue, tarpaulin, hoe, machete, sample ring, meter, scale, knive, crowbar, spade, plastic bucket, ruler, and stationeries. The data of temperature, air humidity, rainfall rate, radiation duration, and intensity of solar radiation (global) were obtained from Geophysics Station, BMKG Karangkates, Malang.

This study used two-factor Separate Plot Design (RPT) and three replications with Randomized Block Design (RAK) basic design. Factor I (main plot) was varieties of sorghum with 5 levels $\left(v_{1}=\right.$ local varieties of Rote; $v_{2}=$ superior varieties of Numbu; $v_{3}=$ superior varieties of Kawali; $v_{4}=$ superior varieties of Super 1 ; and $v_{5}=$ superior varieties of Super 2 ). Factor II (sub plot) is a crop spacing with 3 levels $\left(\mathrm{j}_{1}=70 \mathrm{~cm} \times 25 \mathrm{~cm}, \mathrm{j}_{2}=70 \mathrm{~cm} \times 20 \mathrm{~cm}\right.$, and $\left.j_{3}=70 \mathrm{~cm} \times 15 \mathrm{~cm}\right)$. Observations were performed for 4 times $(25,50,75$, and 100 days 
after planting or HST) on the following parameters: Total Leaf Area, Specific Leaf Area, Leaf Area Index, Crop Growth Rate and Net Assimilation Rate.

Total Leaf Area (TLA). TLA measurements (usually called as Leaf Area Duration/LAD) (Fakorede and Mock, 1980; Kuchay and Zargar, 2016) used Leaf Area Meter (LAM), then the sample was put in oven for 72 hours at $80^{\circ} \mathrm{C}$ until the weight became constant to obtain dry weight leaf.

Specific Leaf Area (SLA). SLA was a comparison between the leaf area and leaf weight containing leaf thickness information that could reflect the photosynthetic organelles unit (closely related to the rate of photosynthesis), where there was a positive relationship between leaf thickness with the number of stomata and chlorophyll content. On the contrary, there was a negative relationship between SLA and photosynthesis rate (Sitompul and Guritno, 1995; Sitompul, 2016).

SLA was calculated by using the formula below (Hunt et al., 2002; Shipley, 2006; Ahmadi et al., 2014; Rana and Rana, 2014; Sitompul, 2016; Li et al., 2016):

$$
S L A=\left(\frac{L A}{L W}\right)
$$

Where SLA = specific leaf area, LA = leaf area $\left(\mathrm{cm}^{2}\right)$, and $L W=$ leaf dry weight $(\mathrm{g})$.

Leaf Area Index (LAI). LAl was closely related to a number of physiological processes such as photosynthesis, transpiration and evapotranspiration (productivity (Gholz, 1982), and the rate of energy exchange between crops and the atmosphere (Gholz et al., 1991 ; Botkin, 1986 in Nel and Wessman, 1993), as it affected the capture of photons and assimilate partitions for the growth and formation of crop yields (Addai and Alimiyawo, 2015).

LAl was calculated by using the formula below (Nel and Wessman, 1993; Sitompul and Guritno, 1995; Addo-Quaye, Darkwa, and Ocloo, 2011; Ramazanzadeh and Asgharipour, 2011; Lukeba et al., 2013; Rana and Rana, 2014; Addai and Alimiyawo , 2015; Sitompul, 2016; Li et al., 2016):

$$
L A I=\left(\frac{L A}{G A}\right)
$$

Where LAI $=$ Leaf Area Index, LA = leaf area $\left(\mathrm{cm}^{2}\right)$, and GA = land area covered by leaf or crop spacing $\left(\mathrm{cm}^{2}\right)$.

Crop Growth Rate (CGR). CGR was a growth index that described the increase of biomass per time unit per (initial) capital unit of the crop. CGR was calculated by the following equation (Watson, 1952; Fakorede and Mock, 1980; Karimi and Siddique, 1991; Sitompul and Guritno, 1995; Ramazanzadeh and Asgharipour, 2011; Addo-Quaye, Darkwa, and Ocloo, 2011; Rahnama, 2006 in Ahmadi et al., 2014; Alikhani, Etemadi, and Ajirlo, 2012; Gul et al., 2013; Rana and Rana; 2014; Sitompul, 2016; Li et al., 2016):

$$
C G R=\left(\frac{d W}{d t}\right)=\left(W_{2}-W_{1}\right) / G A\left(t_{2}-t_{1}\right)
$$

Where CGR $=$ crop growth rate $\left(\mathrm{g} \mathrm{m}^{-2}\right.$ day $\left.^{-1}\right), \mathrm{W}_{1}=$ biomass dry weight at $\mathrm{T}_{1}(\mathrm{~g}), \mathrm{W}_{2}=$ biomass dry weight at $\mathrm{T}_{2}(\mathrm{~g}), \mathrm{GA}$ or $\mathrm{SA}=$ ground area or soil area which was occupied by the sample crop, $T_{1}=$ crop age at observation of $T_{1}$ (day), and $T_{2}=$ crop age at observation of $T_{2}$ (day).

Net Assimilation Rate (NAR). NAR represented the dry weight addition per unit of leaf area (physiological index) per time unit (crop age), where the total dry weight (W) was not constant and had a linear relationship with the leaf area, calculated according to the following equation (Buttery, 1969; Beadle, 1987 Hunt et al., 2002; Shipley, 2006; Addo-Quaye et al., 2011; Ahmadi et al., 2014; Rana and Rana; 2014; Sitompul, 2016; Li et al., 2016; Kuchay and Zargar, 2016):

$$
N A R=\frac{\left(W_{2}-W_{1}\right)\left(\ln L A_{2}-\ln L A_{1}\right)}{\left(L A_{2}-L A_{1}\right)\left(T_{2}-T_{1}\right)}
$$


Where NAR = leaf unit price when total dry weight of crop had a linear relationship with leaf area, $\mathrm{W}_{1}=$ biomass dry weight at $\mathrm{T}_{1}(\mathrm{mg}), \mathrm{W}_{2}=$ biomass dry weight at $\mathrm{T}_{2}(\mathrm{mg})$, In = epixilonbased natural logarithm $(e=2.718), \mathrm{LA}_{1}=$ leaf area at $\mathrm{T}_{1}\left(\mathrm{~cm}^{2}\right), \mathrm{LA}_{2}=$ leaf area at $\mathrm{T}_{2}\left(\mathrm{~cm}^{2}\right)$, $\mathrm{T}_{1}=$ crop age at observation of $\mathrm{T}_{1}$ (day), and $\mathrm{T}_{2}=$ crop age at observation of $\mathrm{T}_{2}$ (day).

\section{RESULTS AND DISCUSSION}

Total Leaf Area. Varieties and crop spacing gave significant influence to TLA at 75 and $100 \mathrm{HST}$ (Figure 1), with the highest TLA value at $75 \mathrm{HST}$ was found in $\mathrm{v}_{5} \mathrm{j}_{1}$ and the lowest was found at $v_{1} j_{1}$, with the respective values of $6,460.3$ and $3,386.4 \mathrm{~cm}^{2}$. On the other hand, at $100 \mathrm{HST}$, the highest value was at $v_{5} j_{1}$ and the lowest was at $v_{3} j_{3}$ with successive values of $7,309.1$ and $3,889.8 \mathrm{~cm}^{2}$. While at 25 and $50 \mathrm{HST}$, the influence of interaction and the main factor was not significant. The closer the crop spacing, the TLA would decrease because the leaves shaded each other so that the lower leaves would lack of light. Therefore, the growth was not normal. TLA differences between varieties were determined by the interaction between varieties and environmental factors in which the crop grew and developed (Saberi and Siti Aishah, 2013). However, there was a tendency that varieties with longer lifespan would have larger TLA values and superior varieties would have larger TLA values than local varieties (Lukeba et al., 2013) because they had more number of leaves and had longer leaf size where there was a linear relationship between leaf number, leaf length and leaf area (Parmar and Chandra, 2002).

Specific Leaf Area. Varieties and crop spacing had significant effect on SLA at 75 and 100 HST (Fig. 2). On the other hand, the effect of interaction and the main factor was not significant at 25 and $50 \mathrm{HST}$. However, there was a tendency that the superior varieties had a larger SLA values. This was thought to be due to superior leaf varieties which had better leaf morphology (thighter and thicker) compared with local varieties (Poorter and Nagel, 2000). The crop spacing that gave a better SLA value was $70 \mathrm{~cm} \times 15 \mathrm{~cm}$, although it did not significantly different with other crop spacing. Lafarge and Hammer (2002) reported that there was no significant difference between the various treatments of crop density to SLA.
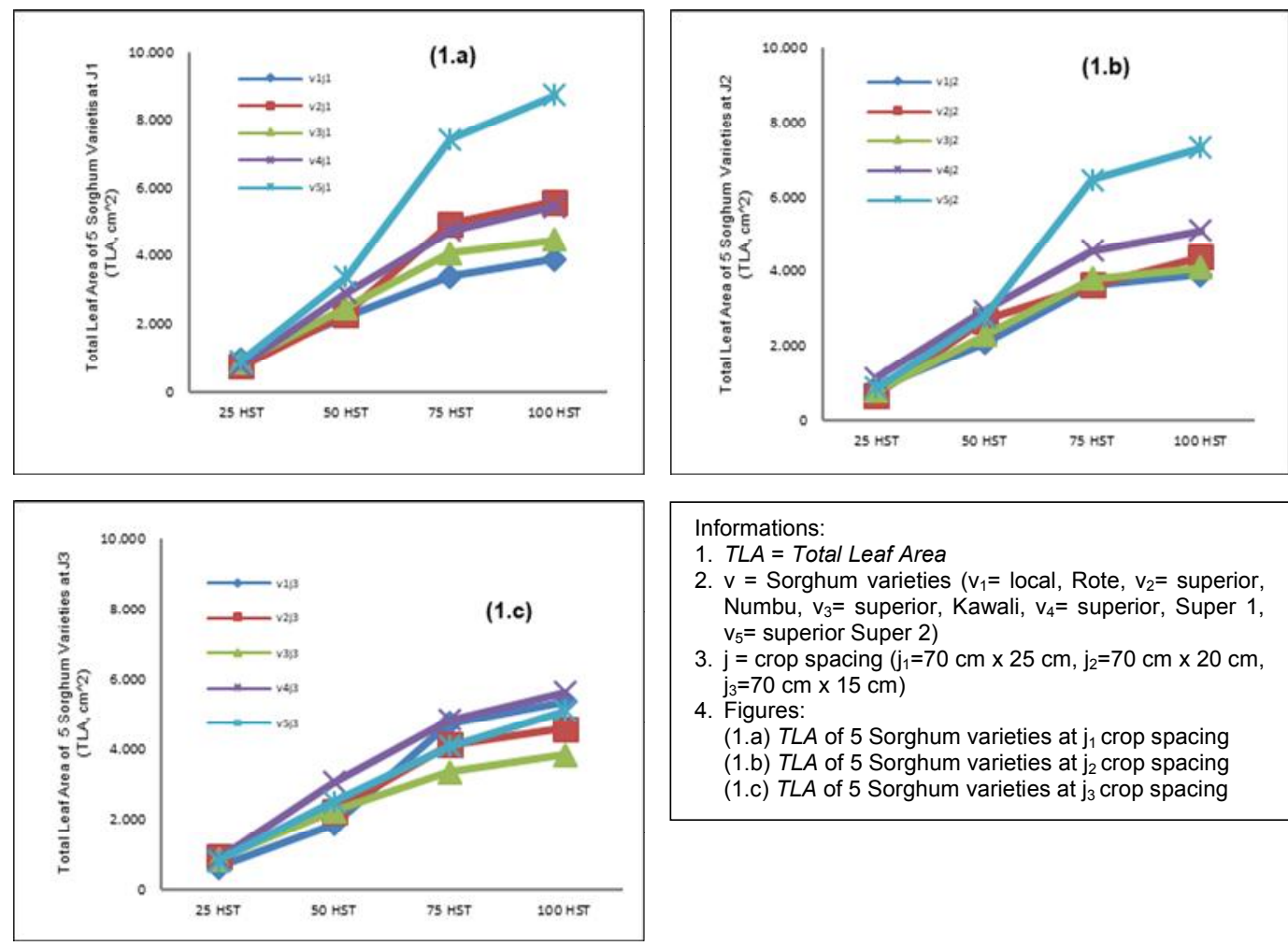

Informations:

1. TLA = Total Leaf Area

2. $v=$ Sorghum varieties $\left(v_{1}=\right.$ local, Rote, $v_{2}=$ superior, Numbu, $v_{3}=$ superior, Kawali, $v_{4}=$ superior, Super 1 , $\mathrm{v}_{5}=$ superior Super 2 )

3. $\mathrm{j}=$ crop spacing $\left(\mathrm{j}_{1}=70 \mathrm{~cm} \times 25 \mathrm{~cm}, \mathrm{j}_{2}=70 \mathrm{~cm} \times 20 \mathrm{~cm}\right.$, $\mathrm{j}_{3}=70 \mathrm{~cm} \times 15 \mathrm{~cm}$ )

4. Figures:

(1.a) TLA of 5 Sorghum varieties at $j_{1}$ crop spacing

(1.b) $T L A$ of 5 Sorghum varieties at $j_{2}$ crop spacing

(1.c) $T L A$ of 5 Sorghum varieties at $j_{3}$ crop spacing

Figure 1 - The Effect of Varieties ( $v$ ) and Crop Spacing (j) on Total Leaf Area (TLA, $\mathrm{cm}^{2}$ ) of Sorghum at Age of 25, 50, 75, and 100 HST for Five Varieties at Three Crop Spacings 

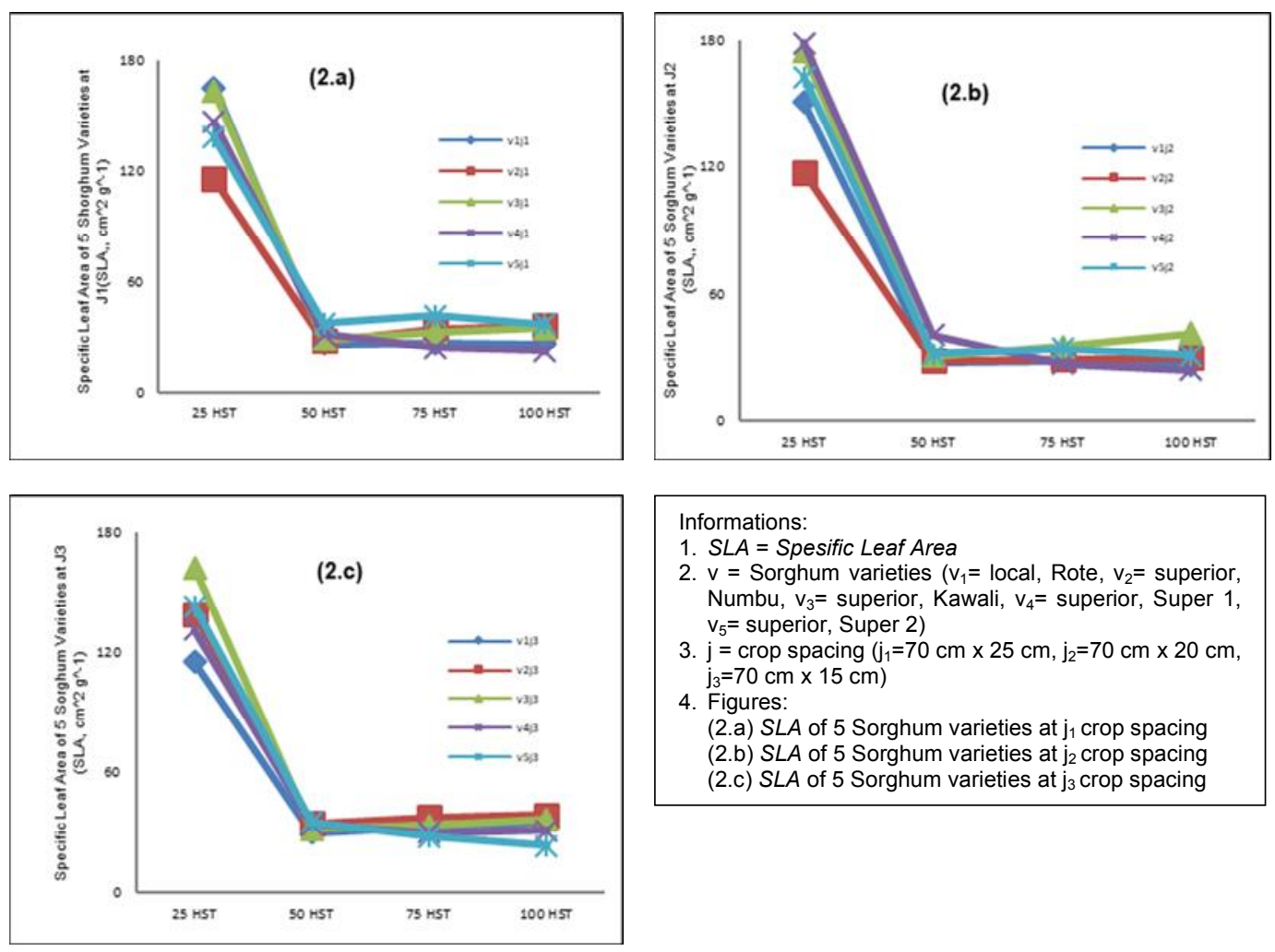
Informations:
1. $S L A=$ Spesific Leaf Area
2. $v=$ Sorghum varieties $\left(v_{1}=\right.$ local, Rote, $v_{2}=$ superior, Numbu, $v_{3}=$ superior, Kawali, $v_{4}=$ superior, Super 1 , $v_{5}=$ superior, Super 2 )
3. $\mathrm{j}=$ crop spacing $\left(\mathrm{j}_{1}=70 \mathrm{~cm} \times 25 \mathrm{~cm}, \mathrm{j}_{2}=70 \mathrm{~cm} \times 20 \mathrm{~cm}\right.$, $\mathrm{j}_{3}=70 \mathrm{~cm} \times 15 \mathrm{~cm}$ )
4. Figures:
(2.a) $S L A$ of 5 Sorghum varieties at $\mathrm{j}_{1}$ crop spacing
(2.b) $S L A$ of 5 Sorghum varieties at $j_{2}$ crop spacing
(2.c) $S L A$ of 5 Sorghum varieties at $j_{3}$ crop spacing

Figure 2 - The Effect of Varieties ( $v$ ) and Crop Spacing (j) on Specific Leaf Area (SLA, $\mathrm{cm}^{2}$ $\left.\mathrm{g}^{-1}\right)$ of Sorghum at Age of 25, 50, 75, and 100 HST for Five Varieties at Three Crop Spacings

At $75 \mathrm{HST}$, the highest SLA value was at $v_{5} j_{1}$ and the lowest was at $\mathrm{v}_{4} \mathrm{j}_{1}$, where the results were 41.8 and $26.7 \mathrm{~cm}^{2} \mathrm{~g}^{-1}$, respectively. While at $100 \mathrm{HST}$, the highest value was at $v_{2} j_{3}$ and the lowest was at $v_{1} j_{2}$, with successive values of 38.9 and $22.4 \mathrm{~cm}^{2} \mathrm{~g}^{-1}$.
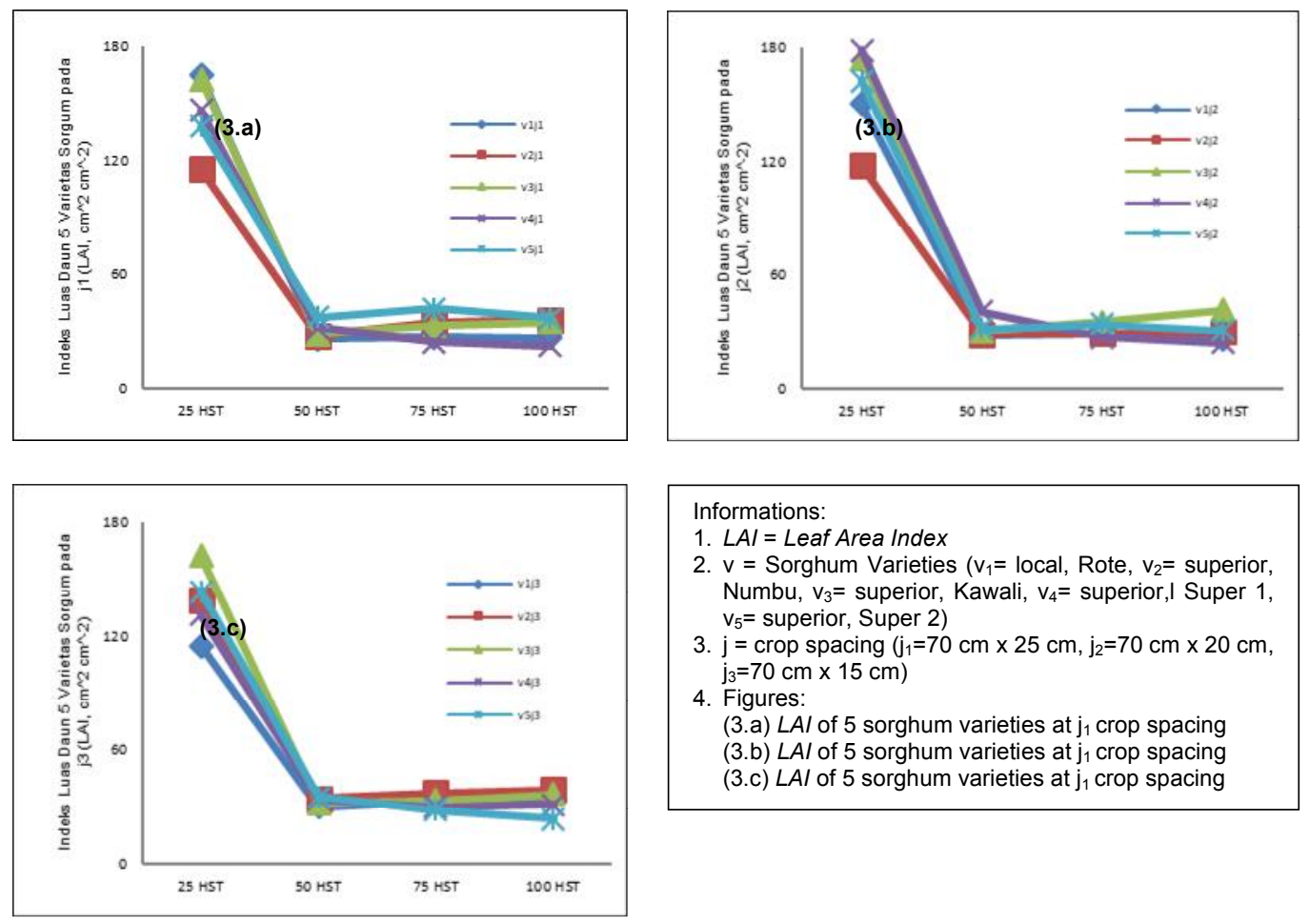

Informations:

1. $L A I=$ Leaf Area Index

2. $v=$ Sorghum Varieties $\left(v_{1}=\right.$ local, Rote, $v_{2}=$ superior Numbu, $v_{3}=$ superior, Kawali, $v_{4}=$ superior,I Super 1 , $\mathrm{v}_{5}=$ superior, Super 2 )

3. $\mathrm{j}=$ crop spacing $\left(\mathrm{j}_{1}=70 \mathrm{~cm} \times 25 \mathrm{~cm}, \mathrm{j}_{2}=70 \mathrm{~cm} \times 20 \mathrm{~cm}\right.$, $\mathrm{j}_{3}=70 \mathrm{~cm} \times 15 \mathrm{~cm}$ )

4. Figures:

(3.a) $L A /$ of 5 sorghum varieties at $j_{1}$ crop spacing

(3.b) $L A l$ of 5 sorghum varieties at $j_{1}$ crop spacing

(3.c) $L A l$ of 5 sorghum varieties at $j_{1}$ crop spacing

Figure 3 - The Effect of Varieties ( $v$ ) and Crop Spacing (j) on Leaf Area Index (LAI) of Sorghum at Age of 25, 50, 75, and 100 HST for Five Varieties at Three Crop Spacings 
SLA appeared high at the beginning, and then it began to decrease sharply in the active vegetative phase and decreased slowly in generative and mature physiological phases because SLA was determined by the interaction between light and nutrient content of the crop (Meziane and Shipley, 1999). SLA was positively correlated with light and nutrient content, therefore, in older and denser crops; they had lower ability to catch light due to lower nitrogen content (Lee, Goudriaan and Challa, 2003; Tei, Scaife and Aikman, 1996; Kuchay and Zargar, 2016). However, there was an inverse relationship between radiation quanta and biomass production where SLA would decrease when the total dry weight of the crop was higher as the age of the crop increased. It suggested that light quanta was more instrumental in driving properties activity in crops (crop metabolism and genetic) compared to the crop biomass production (Sitompul, 2016).

Leaf Area Index. Varieties and crop spacing had a significant effect on LAI at 75 and 100 HST (Figure 3), whereas at 25 and 50 HST, only crop spacing had a significant effect. However, there was a tendency that only superior varieties with longer lifespan would have larger LAl values. It was in line with the opinion of Bueno and Atkins (1982) that LAl would increase in line with the age of the crop. The crop spacing that gave a better LAl value was $70 \mathrm{~cm} \times 15 \mathrm{~cm}$. At $75 \mathrm{HST}$, the highest LAl value was at $v_{5} j_{2}$ and the lowest was at $v_{1} j_{1}$, where the results were 4.61 and 1.9 , respectively. While at $100 \mathrm{HST}$, the highest value was at $v_{5} j_{2}$ and the lowest value was at $v_{1} j_{1}$, where the results were 5.22 and 22.3.

In general, there was a similar tendency between TLA and LAI parameters. At both ages, there was a similar tendency in which the highest LAl values were at $\mathrm{j}_{1}(70 \mathrm{~cm} \times 25$ $\mathrm{cm})$ and $\mathrm{j}_{2}$ crop spacing $(70 \mathrm{~cm} \times 20 \mathrm{~cm})$ for Super 2 varieties, while Super 1 was at $j_{3}$ crop spacing $(70 \mathrm{~cm} \times 15 \mathrm{~cm})$. The high value of LAl on Super 2 varieties was in line with relatively high crop morphology with longer and wider leaf size when compared to the other two superior varieties (Numbu and Kawali). The size of Rote's (local varieties) leaf actually had a length that was almost the same as the Super 2 varieties, but it was narrower, which resulted in lower LAI value.

At the age of 25 and 50 HST, only crop spacing affected the LAI, where the highest LAI value was at the crop spacing of $70 \mathrm{~cm} \times 15 \mathrm{~cm}$ because the crops tended to be dense, causing intercurrent covering.
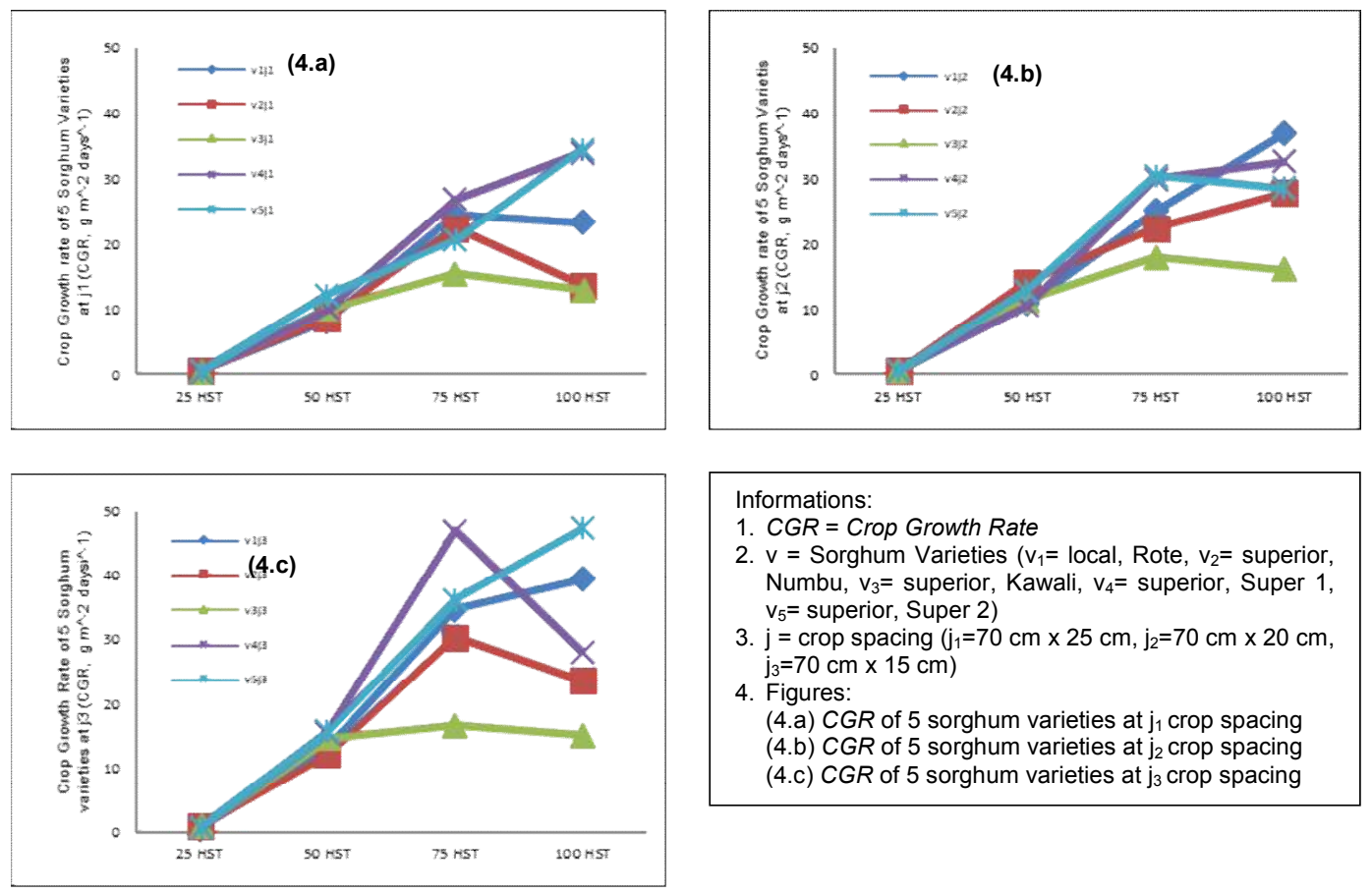

Informations:

1. $C G R=$ Crop Growth Rate

2. $v=$ Sorghum Varieties $\left(v_{1}=\right.$ local, Rote, $v_{2}=$ superior Numbu, $v_{3}=$ superior, Kawali, $v_{4}=$ superior, Super 1 , $\mathrm{v}_{5}=$ superior, Super 2 )

3. $\mathrm{j}=$ crop spacing $\left(\mathrm{j}_{1}=70 \mathrm{~cm} \times 25 \mathrm{~cm}, \mathrm{j}_{2}=70 \mathrm{~cm} \times 20 \mathrm{~cm}\right.$ $j_{3}=70 \mathrm{~cm} \times 15 \mathrm{~cm}$ )

4. Figures:

(4.a) CGR of 5 sorghum varieties at $j_{1}$ crop spacing

(4.b) CGR of 5 sorghum varieties at $j_{2}$ crop spacing

(4.c) CGR of 5 sorghum varieties at $j_{3}$ crop spacing

Figure 4. The Effect of Varieties ( $v$ ) and Crop Spacing (j) on Crop Growth Rate (CGR, $\mathrm{g} \mathrm{m}^{-2}$ day $^{-1}$ ) of Sorghum at Age 25, 50, 75, and 100 HST for Five Varieties at Three Crop Spacings 
Thus, the closer a crop was, the LAl value tended to increase until it reached the optimum value at the time of maximum extinction coefficient (k) (Tei et al., 1996; Alikhani et al., 2012) because LAl was strongly influenced by the canopy structure which consisted of position, size and shape of the vegetative element (Ross, 1981) and the sun angle (Nel and Wessman, 1993). In addition, the PAR diffusion substraction was able to increase the value of LAl (Nel and Wessman, 1993).

Crop Growth Rate. Varieties had significant effect on CGR at age of 75 and 100 HST, while crop spacing had significant effect on CGR at age of 50 and 75 HST (Figure 4). The crop spacing that gave a better NAR value was $70 \mathrm{~cm} \times 25 \mathrm{~cm}$. At $75 \mathrm{HST}$, the highest CGR value was at $v_{4} j_{3}$ and the lowest was at $v_{3} j_{1}$, where the results were 47.009 and $15.472 \mathrm{mg}$ $\mathrm{cm}^{-2}$ day $^{-1}$, respectively. At $100 \mathrm{HST}$, the highest CGR value was at $\mathrm{v}_{1} \mathrm{j}_{3}$ and the lowest was at $v_{3} j_{1}$ with successive values of 39.555 and $12.980 \mathrm{mg} \mathrm{cm}^{-2}$ day $^{-1}$. At the age of $25 \mathrm{HST}$, all treatments were not significant. However, there was an interesting tendency that the closer the crop spacing, then the more the CGR value increased. In addition, long-lived superior varieties were found to have higher CGR compared with shorter-lived superior varieties and local varieties (Rote).

This was in line with what Ramazanzadeh and Asgharipour (2011) reported that CGR tended to be low on initial growth due to imperfect land cover resulting in low light interception due to a lot of passing light. However, as the leaf area increased and the less light passed through the lower canopy layer, the CGR value increased rapidly and reached optimum at flowering/efflorescence stage. The same opinion was expressed by Addo-Quaye and Ocloo (2011), who stated that CGR had a linear relationship with LAI, where the higher perceived light would reslut in higher LAI and CGR value, and vice versa.
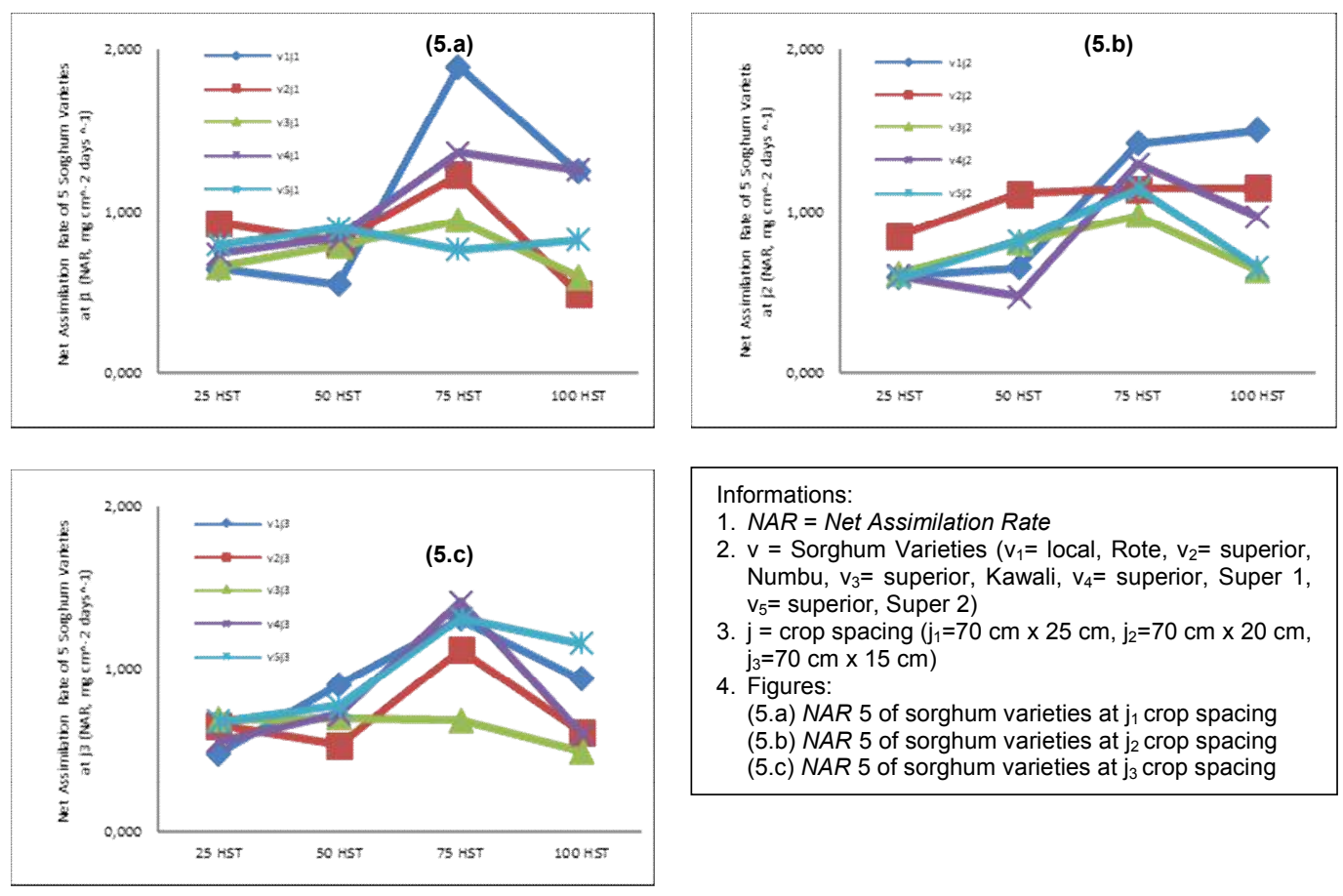

\footnotetext{
Informations:

1. $N A R=$ Net Assimilation Rate

2. $v$ = Sorghum Varieties $\left(\mathrm{v}_{1}=\right.$ local, Rote, $\mathrm{v}_{2}=$ superior Numbu, $v_{3}=$ superior, Kawali, $v_{4}=$ superior, Super 1 , $\mathrm{v}_{5}=$ superior, Super 2 )

3. $\mathrm{j}=$ crop spacing $\left(\mathrm{j}_{1}=70 \mathrm{~cm} \times 25 \mathrm{~cm}, \mathrm{j}_{2}=70 \mathrm{~cm} \times 20 \mathrm{~cm}\right.$, $\mathrm{j}_{3}=70 \mathrm{~cm} \times 15 \mathrm{~cm}$ )

4. Figures:

(5.a) NAR 5 of sorghum varieties at $j_{1}$ crop spacing

(5.b) NAR 5 of sorghum varieties at $\mathrm{j}_{2}$ crop spacing (5.c) NAR 5 of sorghum varieties at $j_{3}$ crop spacing
}

Figure 5 - The Effect of Varieties ( $v$ ) and Crop Spacing (j) on Net Assimilation Rate (NAR, $\mathrm{mg} \mathrm{cm}^{-2}$ day $^{-1}$ ) of Sorghum at Age of 25, 50, 75, and 100 HST for Five Varieties at Three Crop Spacings

Net Assimilation Rate. Varieties and spacing gave a significant effect on NAR only at 50 HST (Figure 5), while at the other three observations had no significant effect, but there was a tendency, where NAR value was low at the beginning, then it peaked at 75 HST and then decreased at $100 \mathrm{HST}$. The crop spacing that gave a better NAR value was $70 \mathrm{~cm} \times 25$ $\mathrm{cm}$. At $50 \mathrm{HST}$, the highest NAR value was at $v_{1} j_{3}$ and the lowest was at $\mathrm{v}_{4} j_{2}$ with successive 
values of 0.903 and $0.479 \mathrm{mg} \mathrm{cm}^{-2}$ day $^{-1}$. Increased NAR values between 50 and 75 HST indicated that crops were at a high rate of photosynthesis (Parmar and Chandra, 2002).

While the tendency of decreasing NAR values at 100 HST showed that crops had shifted from vegetative to generative phases (had entered physiological maturity) (AddoQuaye and Ocloo, 2011) and most of them had aged so that the rate of photosynthesis as well as the nitrogen concentrations contained in low leaves experienced a decrease ( $\mathrm{Li}$ et al., 2016). In addition, NAR was inconsistent with time (Enyi, 1977, Gardner, Pearce, and Mitchell, 1991) and was influenced by LAI. Therefore, NAR would decrease as the crop spacing got closer and leaves began shading each other (when LAI reached optimum), contradicted with NAR and LAI (Buttery, 1969; Machado et al., 2002; Kuchay and Zargar, 2016).

\section{CONCLUSION}

A research aimed at determining morphology, yield, and photosynthesis partition of sorghum varieties at different crop spacing had been done at Agro Techno Park of University of Brawijaya, Jatikerto Village, Kromengan Subdistrict, Malang Regency, East Java, Indonesia. The study used a two-factor separate plot design, where the main plot was varieties and the sub plot was crop spacing. Observations on growth parameters were performed for 4 times $(25,50,75$, and $100 \mathrm{HST})$ which consisted of Total Leaf Area (TLA), Specific Leaf Area (SLA), Leaf Area Index (LAI), Crop Growth Rate (CGR), and Net Assimilation Rate (NAR). The results showed that at $75 \mathrm{HST}$, the highest TLA value was at $v_{5} j_{1}$ and the lowest was at $v_{1} j_{1}$, where the results were $6,460.3$ and $3,386.4 \mathrm{~cm} 2$. While at 100 HST, the highest TLA was at $v_{5} j_{1}$ and the lowest was at $v_{3} j_{3}$, with successive values of $7,309.1$ and $3,889.8 \mathrm{~cm}^{2}$. For SLA parameter, there was a tendency that superior varieties had greater value. At $75 \mathrm{HST}$, the highest SLA value was at $v_{5} j_{1}$ and the lowest was at $v_{4} j_{1}$, with the results of 41.8 and $26.7 \mathrm{~cm}^{2} \mathrm{~g}^{-1}$. While at $100 \mathrm{HST}$, the highest SLA was at $\mathrm{V}_{2} \mathrm{j}_{3}$ and the lowest was at $v_{1} j_{2}$, with successive values of 38.9 and $22.4 \mathrm{~cm}^{2} \mathrm{~g} \mathrm{~g}^{-1}$. LAl at $75 \mathrm{HST}$ indicated that the highest value was at $v_{5} j_{2}$ and the lowest was at $v_{1} j_{1}$, with the results of 4.61 and 1.94. While at $100 \mathrm{HST}$, the highest LAl was at $v_{5} j_{2}$ and the lowest was at $v_{1} j_{1}$ with successive values of 5.22 and 22.3. At $75 \mathrm{HST}$, the highest CGR value was at $\mathrm{v}_{4} \mathrm{j}_{3}$ and the lowest was at $v_{3} j_{1}$, with the results of 47.009 and $15.472 \mathrm{mg} \mathrm{cm}^{-2}$ day $^{-1}$, respectively. At 100 HST, The highest CGR was at $v_{1} j_{3}$ and the lowest was at $v_{3} j_{1}$ with successive values of 39.555 and $12.980 \mathrm{mg} \mathrm{cm}^{-2}$ day $^{-1}$. Superior varieties had a higher value than local varieties for CGR parameter. NAR tended to be low at the beginning and then it peaked at $75 \mathrm{HST}$ and decreased at $100 \mathrm{HST}$. At $50 \mathrm{HST}$, the highest NAR value was at $\mathrm{v}_{1} \mathrm{j}_{3}$ and the lowest was at $\mathrm{v}_{4} \mathrm{j}_{2}$, with the results of 0.903 and $0.479 \mathrm{mg} \mathrm{cm}^{-2}$ day ${ }^{-1}$, respectively. The crop spacing of $70 \mathrm{~cm} \times 25 \mathrm{~cm}$ proved to provide better value for most parameters, except for CGR and SLA, which the crop spacing was $70 \mathrm{~cm} \times 15 \mathrm{~cm}$.

\section{ACKNOWLEDGEMENTS}

The authors expressed their sincere gratitude to Ministry of Research, Technology and Higher Education of Republic of Indonesia that had helped to finance this research through the financing scheme of Doctoral Dissertation Research (PDD) of Fiscal Year of 2016.

\section{REFERENCES}

1. Addai, I.K. \& M. Alimiyawo, 2015. Graphical determination of leaf area index and its relationship with growth and yield parameter of sorghuim (Sorghum bicolor L. Moench) as affected by fertilizer application. Journal of Agronomy 14(4):272-278.

2. Addo-Quaye, A.A., A.A. Darkawa, \& G.K. Ocloo. 2011. Growth analysis of component in a maize-soybean intercropping system as affected by time of croping and spatial arrangement. ARPN Journal of Agricultural and Biological Science 6(6):34-44. 
3. Ahmadi, B., A.H. Rad, \& B. Delkhosh, 2014. Evaluation of crop densities on analysis of growth indices in two canola forage (Brassica napus L.). European Journal of Experimental Biology 4(2):286-294.

4. Alikhani, M.A., F. Etemadi, \& A.F. Ajirlo. 2012. Physiological basis of yield difference in grain sorghum (Sorghum bicolor L. Moench) in a semi-arid environment. ARPN Journal of Agricultural and Biological Science 7(7):488-496.

5. Balitbangtan Kementan. 2013. Sorghum: Inovasi teknologi dan pengembangan. Editors: Soemarno, Dj.S. Darmadjati, M. Syam, dan Hermanto. Badan Penelitian dan Pengembangan Pertanian Kementerian Pertanian. Jakarta.

6. Beadle, C.L. 1987. Crop growth analysis. Techniques in bio-productivity and photosynthesis. 2nd Edn., New York: Pergamon press, Oxford.

7. Biscoe, P. \& A. Wellington. 1984. Timing husbandry to crop development. Farm Business, Warwick, p.32-33.

8. Bueno, A. \& R. Atkins. 1982. Growth analysis of grain sorghum hybrids. lowa State Journal of Agricultural Research. 56:367-381.

9. Buttery, B.R. 1969. Analysis of the growth of soybean as affected by crop population and fertilizer. Can. J. Crop Sci. 49:675-684.

10. Enyi, B.A.C. 1977. Analysis growth and yield of two sorghum varieties. Ghana Jnl agric. Sci. 10:165-176.

11. Fakorede, M.A.B. \& J.J. Mock. 1980. Growth analysis of maize variety hybrids obtained from two recurrent selection programmes for grain yield. New Phytol 85:393-408.

12. Gardner, F.P., R.B. Pearce, \& R.L. Mitchell. 1991. Fisiologi tanaman budidaya. Cetakan pertama. Judul asli: Physiology of crop crops. Penerjemah: H. Susilo. Pendamping: Subiyanto. UI-Press. Jakarta.

13. Garofalo, P., A.V. Vonella, S. Ruggieri, \& M. Rinaldi. 2011. Water and radiation use efficiencies of irrigated biomass sorghum in a Mediterranean environment. Italian $\mathrm{J}$. Agron. 6e(21):133-139.

14. Gholz, H.L. 1982. Environmental limits on above-ground net primary production, leaf area, and biomass in vegetation zones of the Pacific Northwest. Ecology 63(2):469-481.

15. Gholz, H.L., S.A. Vogel, W.P. Cropper, K. McKelvey, K.C. Ewel, R.O. Teskey, \& P.J. Curran. 1991. Dynamics of canopy structure and light interception in Pinus elliotti stands, North Florida. Ecol. Monogr. 61(1):33-51.

16. Gul, H., A.Z. Khan, S.K. Khalil, H.U.R. Rehman, S. Anwar, B. Saeed, Farhatullah, \& H. Akbar. 2013. Crop growth analysis and seed development profile of wheat cultivars in relation to sowing dates and nitrogen fertilization. Pak. J. Bot., 45(3):951-960.

17. House, L.R. 1985. A guide to sorghum breeding. Second edition. International Crops Research Institute for the Semi Arid Tropics (ICRISAT) Patancheru P.O. Andhra Pradesh, India.

18. Hunt, R. 2003. Growth analysis, individual crops. (In) B. Thomas, D.J. Murphy, D. Murray (eds.). 2003. Encyclopedia of applied crop sciences, 588-596. Academic Press, London.

19. Hunt, R., D.R. Causton, B. Shipley, \& P. Askew. 2002. A modern tool for clasiccal crop growth analysis. Annals of Botany $90: 485-488$.

20. Karimi, M.M. \& K.H.M. Siddique. 1991. Crop growth and relative growth rates of old and modern wheat cultivars. Aust. J, Agric. Res. 42:13-20.

21. Kuchay, S.A., 2016. Analysis of growth in some cultivars of Solanum melongena grown in Kashmir. Imperial Journal of Interdisciplinary Research (IJIR) 2(5):397-405.

22. Lafarge T.A. \& G.L. Hammer. 2002. Predicting crop leaf area production: shoot assimilate accumulation and partitioning, and leaf area ratio, are stable for a ide range of sorghum population densities. Field Crops Research 137-151.

23. Lee, J.H., J. Goudriaan \& H. Challa. 2003. Using the expolinier growth euation for modeling crop growth in year-round cut Chrysanthemum. Annals of Botany 92:697-708.

24. Li, X., B. Schmid, F. Wang, \& C.E.T. Paine. 2016. Net assimilation rate determines the growth rates of 14 species of subtropical forest trees PLoS ONE 11(3):1-13. 
25. Lukeba, J-C.L. 2013. Growth and leaf area index simulation in maize (Zea mays L.) under small-scale farm condition in a Sub-Sharan African Region. American Journal of Crop Sciences 4:575-583.

26. Machado, S. 2002. Spatial and temporal variability of corn growth and grain yield: Implications for site-specific farming. Crop Sci. 42:1564-1576.

27. Meziane, D. \& B. Shipley. 1999. Interacting components of interspecific relative growth rate: constancy and change under differing conditions of light and nutrient supply. Functional Ecology. 13:611-622.

28. Nel, E.M. \& C.A. Wessman. 1993. Canopy transmittance models for estimating forest leaf area index. Can. J. for. Res. 23:2579-2586.

29. Nogueira, S.S.S.; V. Nagai, N.R. Braga, M. Do C.S.S. Novo, \& M.B.P. Camargo. 1994. Growth analysis of chickpea (Cicer arietinum L.). Sci. agric., Piracicaba 51(3):430-435.

30. Özalkan, Ç., H.T. Sepetoĝlu, I. Daur, \& O.F. Şen. 2010. Relationship between some crop growth parameters and grain yield of chickpea (Cicer arietinum L.) during different growth stages. Turkish Journal of Field Crops 15(1):79-83.

31. Parmar, N.G. \& S.V. Chandra 2002. Groth analysis using curve fitting method in early and late son sunflower. Planr Breeding and Seed Science 46(1):61-69.

32. Pierce, L.L. \& S.W. Running. 1988. Rapid estimation of coniferous forest leaf area index using a portable integrating radiometer. Ecology 69(6):1762-1767.

33. Poorter, H. \& C. Remkes. 1990. Leaf area ratio and net assimilation rate of 24 wild species differing in relative growth rate. Oecologia 83:553-559.

34. Poorter, H. \& O. Nagel. 2000. The role of biomass allocation in the growth response of crops to different levels of light, $\mathrm{CO} 2$, nutrients and water: a quantitavie review. Aust. J. Crop Physiol. 27:595-607.

35. Poorter, K., 2009. Causes and consequences of variation in leaf mass per area (LMA)-a meta-analysis. New Phytologist 182: 565-588.

36. Ramazanzadeh, S. \& M.R. Asgharipour. 2011. Physiological growth responses of sorghum genotypes to impairment of crop photosynthesis using potassium iodide. Australian Journal of Basic and Applied Sciences 5(11):1884-1890.

37. Rana, S.S. \& R.S. Rana. 2014. Advances in crop growth and productivity. Department of Agronomy, CSK HP Krishi Vishvavidyalaya, Palampur, India.

38. Ross, J., 1981. The radiation regime and architecture of crop stands, The Hague, $391 \mathrm{pp}$.

39. Russelle, M.P., W. Wilhelm, R.A. Olson, \& J.F. Power. 1984. Growth analysis based on degree days. Publications from USDA-ARS/UNL Faculty. Paper 123. http://digitalcommons.unl.edu/usdaarsfacpub/123.

40. Saberi, A.R. \& H. Siti Aishah. 2013. Growth analysis of forage sorghum (Shorghum bicolor L) varieties under varying salinity and irrigation frequency. The International Journal of Biotechnology 2(7):130-140.

41. Shipley, B. 2006. Net assimilation rate, specific leaf area and leaf mass ratio: which is most closely correlated with relative growth rate? A meta-analysis Functional Ecology 20:565-574.

42. Sitompul, S.M. 2016. Analisis pertumbuhan tanaman. Cetakan pertama. UB Press. Malang.

43. Sitompul, S.M. \& B. Guritno. 1995. Analisis pertumbuhan tanaman. Cetakan pertama. Gadjah Mada University Press. Yogyakarta.

44. Srivastava, B.K. \& R.P. Singh. 1980. Morpho-physiological response of garden pea (Pisum sativum L.) to sowing dates. II- Growth analysis. Indian J. of Hort. 382-389.

45. Tei, F, A. Scaife \& D.P. Aikman. 1996. Growth lettuce, onion, and red beet. 1. Growth analysis, light interception, and radiation use efficiency. Annals of Botany 78:633-643.

46. Watson, D.J. 1952. The physiological basis of variation in yield. Advances in Agronomy, New York 4:101-145.

47. Watson, D.J. \& K. Hayashice. 1965. Photosynthetic and respiratory components of the net assimilation rates of sugar beet and barley. New Phytologist 64(1):38-47.

48. Wilson, W.J., 1981. Analysis of growth, photosynthesis and light interception for single crop stand. Ann. of Bot. 8:507-512. 